\title{
Development of Media Research in Estonia
}

\author{
Peeter Vihalemm
}

Regular empirical media research began in Estonia in 1965. The mid-1960s was the period of the birth of empirical social sciences in general in Estonia. Although some successful and influential attempts of empirical social research were made in the late 1920 s and 1930s, the tradition of regular research was not established before World War II.

Until the late $1950 \mathrm{~s}$, empirical social sciences did not exist in the Soviet Union. Instead of research, society was described by using ideological constructions of the Communist Party history. These were much more closed to religion than to science. Krushchev's thaw brought some democratic changes into political life and ideology but did not change the suspicious and hostile attitude towards empirical social research as an "alien bourgeois activity." The years 1958-1964 has been called the embryonic period of Soviet sociology (Shlapentokh 1987: 13-32) - in 1958 the Soviet Sociological Association was established and in 19611964 the first sociological research units were established in Moscow, Leningrad and Novosibirsk. Young people who had contacts with Western sociologists and who had had opportunities for scholarship in the West often headed the units. It was one of the reasons why sociology was by that time viewed by officials with suspicion.

Attitudes towards sociology started to change in the middle of the 1960s. Empirical sociological research expanded into many areas of study and began to spread across the country. Sociology deserved official recognition and was very popular in society; sociologists enjoyed both official and popular prestige. It happened in connection with Premier Kosygin's plans for economic reforms in the USSR. Attempts at reforming the USSR's economy

Department of Journalism and Communication, University of Tartu, Ülikooli 18, EE-Tartu 50090, peetervi@ut.ee could not be based only on ideological mythology but presumed a more or less objective picture of economic and social reality based on actual data. The forceful introduction of empirical sociology in 1965-1966 was closely connected with these reform plans (which were never fully implemented). Fruitful development continued for several years, even in the beginning of political and ideological stagnation after the crackdown on democratic developments in Czechoslovakia. The years 19651972 have been called the golden age of Soviet sociology (Shlapentokh 1987: 33-56).

The possibilities for empirical sociological research were actively put to use in Estonia. Due to close contacts with democratic-minded young sociologists in Leningrad and Moscow, and easier access to Western literature (especially through Finnish contacts), students of Tartu University showed great interest towards the introduction of empirical social studies. One of the first areas of the newborn empirical social studies was media research. A pioneer in the field of media studies was Ülo Vooglaid, on whose initiative the first comprehensive professional audience survey by the Tartu local newspaper Edasi was conducted in 1965. This was one of the first representative surveys of a media audience in the Soviet Union. During 1966-1969, Edasi also carried out a large program of additional empirical research, which involved polls, experiments, and observations (Vooglaid 1972).

In 1967 Ülo Vooglaid established the Laboratory of Sociology at Tartu University, which developed within a short period into an influential centre for regular media research across all the Soviet Union. Another centre was established in Tallinn, where in 1965-1966, research groups at Estonian Radio and Estonian Television started studying the structure and interests of radio and television audiences.

Annual conferences on mass communication theory organised by the Sociological Laboratory of 
Tartu University at Kääriku near Tartu from 1966 to 1969 bridged the gap between empirical media studies, which were rapidly developing in Estonia as elsewhere in the Soviet Union, and the contemporary theoretical paradigms of Western mass communication research. At these conferences, young researchers from many Russian universities and Tartu University discussed relations between the media and society, media and personality, and media and mass culture. Unfortunately, any participation by researchers from outside the Iron Curtain was impossible; nevertheless these conferences were very prestigious (Shlapentokh 1987: 38).

After the first three Kääriku conferences, their proceedings - detailed reports of discussions, outlines of social gatherings during the conferences, cartoons of participants, anecdotes and doggerel were published. These editions, printed in the printing house of Tartu University, were practically uncensored and accurately conveyed the free atmosphere at the conferences, which was very unusual in the bureaucratised and ideologised world of Soviet social sciences. This free atmosphere was one reason why three mimeographed small books on cheap paper became well known and popular among media researchers across the Soviet Union. Another reason was their content. The Kääriku I proceedings were titled Methodological Problems of Mass Communication Research and included outlines of different sociological and social-psychological approaches to the media (structural functionalism, theory of cognitive dissonance, symbolic interactionalism) without any ideological phraseology, which usually characterised all Soviet publications in social sciences (Kääriku I 1967). Kääriku II was titled Value Orientations and Mass Communication, discussing mainly the problems of personal and social effects of the media and mechanisms of their influence (Kääriku II 1968). Many of these problems were also discussed during Kääriku III, where the main topic was Personality and Mass Communication (Kääriku III 1969).

The main purpose of the rapidly growing media research at the end of the 1960s was practical: to create feedback from the audiences to the editorial staff of newspapers and broadcasting companies. At the same time, in these conditions, media research in Estonia also acquired a critical objective - to give journalists an insight into the process of media consumption, into real attitudes and preferences of audiences, and thus provide journalists with arguments which would give more weight to people's real interests as an alternative to official ideological demands. Using the methodology, which was quite similar to the "uses and gratifications" model, Estonian media researchers carried out comparative analyses of audience interests with the structure of media content. The results were used not only for practical guidance of the editorial staff but by researchers as a tool of measuring social distance between different audience groups and communicators. In the Soviet system, media content was created, structured and filtered strictly according to the rules established by the Communist Party, and thus the discovered conflict between audiences' expectations and the content provided by the censored media also served as an indicator of the growing gap between official ideology and people's needs and values.

Without any survey it was clear that what the Soviet media network offered was largely in conflict with the interests and expectations of the people; however, journalists and liberal officials needed scientific arguments to introduce major changes. As official Soviet ideology included "scientific methods" as a very important concept, the Communist Party tried to lend a "scientific character" to all its activities.

This fledging branch of sociology quickly spread into areas monopolised by the Communist Party, threatening, among other things, the bureaucracy's monopoly on information channels. That is why after the failure of economic reform and the ruthless crackdown on the Prague events in 1968, the Communist Party placed a firm grip on sociology. It was only with the permission of the special commission at the Central Committee of the Communist Party that a sociological research effort could be conducted, and even with permission, publishing the collected data was often difficult in Estonia and practically impossible abroad.

Nevertheless, media research in Estonia soon produced tangible results, which led to some changes in media content and journalistic forms. Supported and encouraged by survey results, the Tartu newspaper Edasi followed everyday life and popular attitudes in the late 1960s much more closely, and its circulation increased from 44,000 in 1964 to 91,000 in 1969. The launching of Estonian Radio's second programme in 1967, which combined current news and music, was similarly based on research into listeners' interests and expectations.

\section{Media Research in the 1970s and 1980s}

The system of control over public life, which had relaxed somewhat in the 1960 s, regained force in 
the early 1970s. In 1970 the Kääriku conferences on mass communication research were prohibited and the proceedings of the fourth conference in 1969, Mass Culture and Mass Communication, could not be published. In 1975 the Laboratory of Sociology at Tartu University was closed down on the orders of the Central Committee of Estonian Communist Party with the assistance of the KGB.

The same kind of developments took place everywhere in the Soviet Empire. The years 1973-1975 have been called the time of purges in Soviet sociology (Slapentokh 1987: 13). Restrictions and repressions, which began in 1969 but developed slowly at first, got into full swing some years later (Ibidem: 43-56). Repressions struck mainly against critically oriented academic media sociology. Practically oriented professional media research in Estonia continued to develop and became institutionalised. In 1969 a sociological research group started to work at Estonian Radio, a year later at Estonian Television. From 1970 onward, these groups conducted quarterly panel surveys of radio and television audiences via listeners' and viewers' diaries. Besides regular monitoring of audience structure, these groups examined the interests and expectations of the audience, including construction of empirical typology of viewers and listeners. For many years during the late 1970s and early 1980s, there was also a regular content analysis of Estonian Radio and Estonian Television broadcasts.

Despite repressions, academic media research also found ways to survive, using the cover of journalism studies. In 1976 the training of journalists at Tartu University was reorganised. In 1954-1976, journalism was offered as a special program in the Department of Estonian Philology; students could choose it to specialise in after two years of general philological studies. Since 1976 journalism studies have been based on their own curriculum and own admittance of students. In 1978 the Department of Journalism was established, chaired by Professor Juhan Peegel, a well-known folklorist and press historian, who founded academic journalism training in Estonia in 1954. Research activities in the Department of Journalism concentrated on two main directions: Estonian press history (Juhan Peegel, Epp Lauk) and media sociology (Marju Lauristin, Peeter Vihalemm, Andrus Saar, Hagi Shein; the latter two worked mainly in Tallinn, participating in research groups at Estonian Radio and Estonian TV). As journalism in Tartu University was officially a branch of Humanities, it was considered to be less dangerous for the political sys- tem. Since the mid-1970s, research activities concentrated on areas which were less important for the Communist Party officials and less controlled by them: the readership and content of the local press and cultural weekly, book consumption.

In the 1970s, the first PhD dissertations in the field of media research in Estonia were completed. Ülo Vooglaid defended his dissertation on audience research in 1970 at the Institute of Sociology in Moscow, Peeter Vihalemm on the reception of newspapers texts in 1974 at Leningrad University, Marju Lauristin on content analysis in 1976 at Moscow University, and Andrus Saar on functional typology of radio broadcasts in 1977, also at Moscow University. Unfortunately, all publications connected with these dissertations are only available in Estonian and Russian. According to Soviet rules, all dissertations (including dissertations on dialects of national languages) could be written only in Russian. Furthermore, the empirical results of surveys could not be published at all, as they were considered to be "for official use only." This meant that for decades, Estonian media sociology developed without the open academic communication with colleagues abroad, except for a few instances based on personal contacts with Finnish researchers.

\section{Control over Media and Sociological Research by the Soviet Regime}

The reason why Estonian media research could continue to develop more freely compared to the total ideological control exercised over the studies of Russian-language central press and broadcasting in Moscow or Leningrad, can be understood only in the context of knowledge about the hierarchical system of political control in the Soviet Union.

Five levels of control and ideological canonisation can be distinguished in the Soviet media (Vihalemm and Lauristin 1997) that included all aspects of the media: channels, sources and authors, themes and topical areas, scales of events and genres (see Table 1).

The first and the highest level of control was exercised every day over the production of all texts which were highly canonised. It concerned the AllUnion party press, primarily the newspaper Pravda (Truth) and all Russian-language party press in the Union republics (in case of Estonia it was the newspaper Sovetskaya Estonia). The main source of information on this level was the news agency TASS, which in reality was a department of the 
Central Committee of the Communist Party and functioned as the Orwellian Ministry of Truth, not a journalistic institution. The production of TASS was anonymous; the majority of the identified authors on this level were leading officials of the Communist Party and journalists with special status.

The second level of control included the Communist Party press in the national languages, news broadcasts in the electronic media, and coverage of local ideological, political and historical themes as well as economics, where since Khrushev's thaw it was possible to express some criticism in analytical commentaries. On this level, a strict ideological control was implemented more flexibly: certain local variances of interpretations and modulations of canonical texts were permitted and not all texts were carefully controlled.

An important feature of the Soviet-era Estonian journalism was the permanent struggle for widening the borders of publicly permitted topics and journalistic forms. This struggle had visible results on the third, medium level of control, which was specific for the local press on one hand and for the specialised magazines and journals on the other hand. Here, the external control was looser and the duties of internal censorship were given to the chief editors. The extent of their courage determined the extent to which the limits of canonisation and standardisation could be broadened. Many Estonian editors and journalists actively used these opportunities.

More freedom of expression was allowed in the cultural press. It could be considered the fourth and lowest level of control in the hierarchy of legal press. On cultural pages journalists used complicated forms of indirect expression: metaphors, analogies, allusions and parodies. Readers learned to read between the lines, to catch hints and draw parallels. Critical ideas about Soviet reality were often expressed in the form of art criticism.

In the censored and ideologically edited version of reality described by the Soviet official media, people did not recognise their own experiences. A remarkable proportion of real problems and events were never reflected in the media content because they did not correlate with the approved positive standard (see e.g., Manaev 1989). For example, open resistance to the system, poverty, crime and other social delinquencies, even diseases and accidents, could not exist in Soviet conditions. These "forbidden topics" could be found only in the alternative, underground or foreign media channels. These channels can be viewed as the fifth level of media hierarchy, which existed out of the reach of Soviet censors.

The same kind of control hierarchy functioned also for scientific activities - both for research institutions and topics of research. To the first level of total control belonged research institutions in Moscow and Leningrad and all research groups connected with military industry. To the second level of control - institutes of the Academy of Science in Soviet republics and all research groups dealing with the history of the Soviet Empire and the Communist Party. To the third level of control other research institutions in the capitals of the Soviet republics, as well as national universities and trustful research groups in social sciences, economy and law representing official ideology. To the fourth level of control - provincial universities and higher education institutions, less trustful research groups in social sciences. Tartu University as a national learning institution officially belonged to the third level, but it was located outside the capital Tallinn and in practice was usually controlled as an institution of the fourth level. As a result, journalism graduates from Tartu University were not trusted enough to work in media channels of the first and second levels of importance.

In Soviet sociology there was a clear difference between official sociology, which was so tightly connected with the ideological activities of the Communist Party that Shlapentokh called it party sociology, and academically oriented professional sociology (1987: 80-106). Official sociology belonged to the first, second or third level, depending on location and status of the research group: in Moscow, mainly to the first level, in some cases to the second; in Leningrad and other larger Russian centres, mainly to the second level; and in the national republics, mainly to the third level, in some cases to the second. Official sociologists were much more trusted and had more opportunities for publishing, financing, travelling abroad, etc. For their professional career, loyalty to the Communist regime and good friends inside the nomenklatura were much more important than high professional competence.

Research groups at Estonian Radio and TV belonged to the third level of control. It meant that they had access to news broadcast research and even to audience research of the Finnish TV, Voice of America and Radio Free Europe. But it also meant that the results of Estonian Radio and TV audience research were half-secret; they were restricted to official use and were available only for radio and TV authorities, not for ordinary journal- 
Table 1. Hierarchies of Political Control and Ideological Canonisation in Soviet Press

\begin{tabular}{|c|c|c|c|c|c|}
\hline $\begin{array}{l}\text { Level of control } \\
\text { and canonisation }\end{array}$ & Channels & Sources, authors & Themes, topical areas & Scale of events & Genres \\
\hline $\begin{array}{l}\text { 1. Total control, produc- } \\
\text { tion of canonical texts }\end{array}$ & $\begin{array}{l}\text { All-Union Communist } \\
\text { Party (CP) press (e.g., } \\
\text { Pravda), Russian-language } \\
\text { CP press in Soviet republics } \\
\text { (e.g., Sovetskaya Estonia) }\end{array}$ & $\begin{array}{l}\text { Leading CP officials, } \\
\text { TASS; leading official } \\
\text { journalists }\end{array}$ & $\begin{array}{l}\text { Ideology, Party politics, } \\
\text { All-Union government, } \\
\text { foreign policy and inter- } \\
\text { national affairs, history of } \\
\text { CP, history of USSR }\end{array}$ & International, All-Union & $\begin{array}{l}\text { Editorial, political } \\
\text { commentary, all-Union } \\
\text { political, economic news, } \\
\text { foreign news }\end{array}$ \\
\hline $\begin{array}{l}\text { 2. Strong control, } \\
\text { variation of canonical } \\
\text { texts }\end{array}$ & $\begin{array}{l}\text { CP press in national } \\
\text { languages }\end{array}$ & $\begin{array}{l}\text { Party bureaucrats } \\
\text { (apparatchics), local } \\
\text { branches of TASS, local } \\
\text { nomenclature, official } \\
\text { journalistic elite, }\end{array}$ & $\begin{array}{l}\text { Economy, statistics, local } \\
\text { CP organisations, local } \\
\text { governments, Soviets, }\end{array}$ & Republican & $\begin{array}{l}\text { Articles, columns, local } \\
\text { economic and political news }\end{array}$ \\
\hline $\begin{array}{l}\text { 3. Medium control, } \\
\text { institutionalised self- } \\
\text { censorship, exploring } \\
\text { and broadening limits } \\
\text { of 'permitted' }\end{array}$ & $\begin{array}{l}\text { Local newspapers, } \\
\text { Komsomol press, } \\
\text { youth magazines }\end{array}$ & $\begin{array}{l}\text { Professional journalists, } \\
\text { local correspondents, } \\
\text { local }\end{array}$ & $\begin{array}{l}\text { Work, Soviet way of life, } \\
\text { education }\end{array}$ & Local & Feature, interview, reportage \\
\hline $\begin{array}{l}\text { 4. Low level of official } \\
\text { control, in-group } \\
\text { control, self-censor- } \\
\text { ship, non-canonical } \\
\text { texts, language games }\end{array}$ & $\begin{array}{l}\text { a) Cultural and scientific } \\
\text { press } \\
\text { b) Women's magazines, } \\
\text { Sport magazines, social } \\
\text { pages of local papers }\end{array}$ & $\begin{array}{l}\text { a) Professional artists, } \\
\text { scientists, critics, } \\
\text { experts } \\
\text { b) Local correspondents, } \\
\text { community workers, } \\
\text { ordinary people }\end{array}$ & $\begin{array}{l}\text { a) Fine arts, cultural life, } \\
\text { research, nature } \\
\text { b) Sport, social affairs, } \\
\text { community life, family }\end{array}$ & $\begin{array}{l}\text { a) Professional } \\
\text { community } \\
\text { b) Individuals }\end{array}$ & $\begin{array}{l}\text { a) Essay, scientific article, } \\
\text { review, parody } \\
\text { b) Feature, interview, } \\
\text { feuilleton }\end{array}$ \\
\hline $\begin{array}{l}\text { 5. Absence of official } \\
\text { control, hidden } \\
\text { surveillance }\end{array}$ & $\begin{array}{l}\text { 'Samizdat', alternative } \\
\text { press }\end{array}$ & Dissidents & $\begin{array}{l}\text { Critique of the Soviet } \\
\text { system and official } \\
\text { ideology }\end{array}$ & Underground & News, commentaries \\
\hline
\end{tabular}


ists or the broader public. Results about the audiences of foreign radio and TV were a complete secret and went directly to the Communist Party and KGB offices. The research group of the Department of Journalism at Tartu University belonged to the fourth level of control and did not have access to all research topics but in turn was much more free in the use of its results, except in publications abroad and, to a lesser extent, in Moscow. It is important to mention here that the academic staff in the Department as well as in all Tartu University were quite free in classroom teaching.

Areas and topics of research did not have such a clear hierarchy of control but one can find similar tendencies. To the level of complete secret and total control belonged topics connected with the military and foreign policy, which was always controlled by the KGB. To the second level - the history of the Soviet Union and the Communist Party that was under the immediate control of representatives of the Communist Party central or district committees. To the third level - all other politically or ideologically sensitive topics controlled by Communist Party officials in research institutions.

A similar hierarchy also functioned inside different disciplines. Shlapentokh analyses two research areas in his book, the sociology of work and the mass media and public opinion, clearly demonstrating that they belong to different levels of control and canonisation (1987: $133-180$ ).

The international co-operation of researchers was strictly limited, even if it was between the socalled socialist countries. In the case described below concerning co-operative Leningrad-EstoniaLithuania-Hungary research, the topic seemed to be ideologically neutral. Environmental protection in the Soviet ideological system perhaps belonged to the fourth level of importance. But even in this case, all international exchange was forbidden after the collection of empirical data.

\section{Contacts with Nordic Media Researchers}

Despite these difficulties, Estonian media researchers had some contacts with their Nordic colleagues, especially from Tampere University in Finland. In May 1972, Tapio Varis visited Tartu for some hours as a tourist and met occasionally with Marju Lauristin, who was at that time the director of the Laboratory of Sociology. To visit Tartu was not easy, as it was a closed city for foreigners due to the large military airport partly located in the terri- tory of the city, three kilometres from the main building of the University. For that reason foreigners could not stay in Tartu overnight, and every foreign visitor was registered by the University's foreign office.

For Tartu media researchers regarded as not trustworthy by the authorities, it was even more difficult to visit Western countries. Only in July 1977 could Marju Lauristin visit Tampere as a tourist, and during this visit more regular exchanges between Estonian and Finnish media researchers were discussed. In August 1978, Marju Lauristin, as a member of a tourist group, participated in the World Sociological Congress in Uppsala. During this event several contacts were established and among them were regular contacts with Professor Karl Erik Rosengren from the University of Lund. After the liberation of Estonia, these contacts led to the establishment of the Swedish-Estonian comparative research programme BALTICOM.

In the early 1980s, some possibilities for contacts with Finnish colleagues occurred in connection with Soviet-Finnish seminars on mass communication research. The second seminar was held in Tampere in May 1981. The presentation by Marju Lauristin was in the program and the text was published in the proceedings (Lauristin 1982), but Marju Lauristin herself was by this time on the black list of "seriously mistaken" people who could not travel abroad due to the signing of the dissenting Letter of Forty (see e.g., Misiunas and Taagepera 1993: 269).

Media researchers both from Tartu and Tallinn participated in the third Soviet-Finnish seminar in Leningrad in May 1983, and researchers from Tampere visited Estonia in May 1984. Nevertheless, Estonian-Finnish research contacts were irregular. Regular international contacts were only established in 1989-1990 and then, besides Tampere, also with the Universities of Oslo, Lund, Göteborg, Stockholm, Helsinki, Jyväskylä and Aarhus.

The contacts with Nordic colleagues were also an important window to scientific information from the other Western centres. Regular access to the research papers of Tampere University and to the journal Tiedotustutkimus gave Estonian researchers, due to their knowledge of Finnish language, the opportunity to follow theoretical developments and current debates in Western communication research more easily than through the English-language sources which were accessible only in special "closed" sections of the academic libraries in Moscow. 


\section{Topics and Traditions of Research in 1965-1991}

The best-examined area of mass communication processes in Estonia is audience structure. Audience surveys were started in 1965, with regular radio and television audience monitoring beginning in 1970 (see Table 2). During Soviet times, the audience of the print media was examined much less regularly. The bulk of the results of Soviet-era audience research is stored in the Estonian Social Science Data Archive at Tartu University and is available for researchers (www.psych.ut.ee/esta).

In the 1970s and 1980s, content analysis was used more actively and regularly than in the 1990s, including some large research projects which tried to collect data about all the main aspects of the mass communication process.

The first complex media research project in Estonia was connected with the newspaper Edasi. During 1965-1975, its audience, content and journalists' orientations were examined as well as three series of experiments conducted on the reception of texts from Edasi. There are several reasons why this paper is so comparatively well researched - it was officially a local paper and belonged to the third level of control and canonisation (which continued even after becoming in fact a nationwide paper). Experiments were allowed in its content and journalistic forms as well as active co-operation with researchers.

The research into the local press in 1979-1986 can be considered as the second large and complex project. Large surveys yielded substantial data about the living conditions, lifestyle and value orientations of different groups of the population, and media use was interpreted in the context of everyday life of the respondents, using both quantitative and qualitative methods of interpretation (Vihalemm 1984; Hion, Lauristin and Vihalemm 1988). Combining statistical cluster analysis with an in-depth analysis of some central representatives of clusters (creating their typological portraits on the basis of answers to the large questionnaires) enabled connections to be drawn from tendencies in media use to cultural and social activities and living conditions.

Table 2. Empirical Media Research in Estonia

\begin{tabular}{|c|c|c|c|}
\hline & Monitoring & Experiment & Text Analysis \\
\hline Journalists & & $\begin{array}{l}\text { local press, 1970-71, } \\
\text { 1979-80; all channels, } \\
\text { 1988-89, 1995-96 }\end{array}$ & \\
\hline Content & $\begin{array}{l}\text { radio \& TV, 1978-87 } \\
\text { advertisements (all } \\
\text { channels), since 1993; } \\
\text { coverage of ethnic } \\
\text { relations (press), } \\
\text { since } 1999\end{array}$ & & $\begin{array}{l}\text { Content analysis: local } \\
\text { press, 1968-76, 1979-86, } \\
\text { since 1998; weeklies, } \\
\text { 1975-78, since 1998; } \\
\text { magazines, 1987; TV- } \\
\text { news, 1973-75; coverage } \\
\text { of Estonia ferry cata- } \\
\text { strophe, all channels, } \\
\text { 1994-1996. } \\
\text { Discourse analysis: } \\
\text { press, since } 1994\end{array}$ \\
\hline
\end{tabular}

\begin{tabular}{|c|c|c|c|c|}
\hline Audiences & $\begin{array}{l}\text { print media since } 1992 ; \\
\text { radio \& TV since } 1970\end{array}$ & $\begin{array}{l}\text { local press, 1965-70; } \\
\text { 1979-86, 1998-1999; } \\
\text { weeklies, 1975-78, 1998 } \\
\text { magazines, 1987-89; } \\
\text { books, 1979-90; } \\
\text { radio, 1965-94, 1999; } \\
\text { TV, 1966-89; }\end{array}$ & & \\
\hline Effects & & $\begin{array}{l}\text { press, } 1980-81 \text {, } \\
\text { since } 1991\end{array}$ & $\begin{array}{l}\text { local press, 1971-75; } \\
\text { audiovisual } \\
\text { commercials, 1971-75 }\end{array}$ & \\
\hline $\begin{array}{l}\text { Functions, Context } \\
\text { of Media Use }\end{array}$ & & $\begin{array}{l}\text { press, 1979-86, since } \\
\text { 1998; books, 1977-90; } \\
\text { radio, 1974-77 }\end{array}$ & & $\begin{array}{l}\text { local press, 1979-86; } \\
\text { radio, 1974-77 }\end{array}$ \\
\hline
\end{tabular}


The third large project Estonian media researchers carried out in 1980s was to assess the influence of the media on environmental attitudes in co-operation with sociologists from Leningrad, Vilnius and Budapest. This study was planned as a comparative research effort using the same questionnaires and content categories in all four countries. The results of large surveys and comparative content analysis led to conclusions about the environmental attitudes of different groups of the population and about the role of the media in their formation. The most interesting conclusion was perhaps the empirical typology of environmental consciousness and the comparison of it with environmental discourses in the media (Lauristin and Firsov 1987; Lauristin 1991). Although the results of the project had high scientific value, it was unfortunately not finalised as a fully comparative project according to its initial design. It developed that the researchers were not permitted to make direct comparisons between the data sets from the Soviet Union and Hungary. It was made clear that international comparative analysis belonged to the highest level of ideological control and these kinds of comparisons were not allowed for research groups who did not represent the official sociology.

The fourth large project of the 1980s was the research about book consumption in Estonia, with five large waves of surveys carried out during 1979-1989. The buying and reading of books was analysed in the context of life-style, activities and interests of different social groups. The typology of book buyers and an analysis of their reading preferences (Lauristin and Vihalemm 1986) demonstrated that cultural stratification in the 1980s in Estonia was much weaker compared to Western countries (and compared to Estonia today). Cultural activities in Soviet-era Estonia were very high in all social groups. National culture functioned as one of the fields of resistance to the totalitarian regime.

In co-operation with Leningrad sociologists, led by Vladimir Yadov, certain traditions of empirical research were formed during 1968-1972 in the Laboratory of Sociology at Tartu University. General principles of research can be characterised as the following:

1. Complexity of the approach and an analysis of all research objects in their social context (e.g., data collection not only about newspaper reading but also about its social and cultural context - general interests and orientations, living conditions, leisure activities, etc.).
2. Detailed character of initial data, detailed and concrete empirical indicators.

3. Analysis of the data on different levels of generalisation - on the lowest level of initial data, then rising to the aggregated characteristics (indices), cluster analysis and empirical typologies.

Based on these principles, the primary method of data collection has been a large survey using questionnaires of $60-90$ pages (800-1000 characteristics) that were often supplemented by an additional interview. On the basis of these initial data, 50 to 80 aggregated characteristics (indices) were usually constructed; for further generalisation, the majority of the indices were subjected to typological analysis (automatic classification of respondents on the basis of a certain pattern of characteristics). Sometimes content analysis has also been conducted on the basis of the same principles - for analysing the social orientation of the Edasi, 254 initial categories were integrated into 40 indices, and from these, eight types of texts were constructed (Lauristin 1976).

On the basis of a large survey, several typologies have been often created. A respondent would be characterised as belonging to different types at the same time - to a particular type of newspaper reading, to another type of book consuming, to a third of value orientations, to a fourth of leisure activities, to a fifth of living conditions, etc.

Typological analysis of newspaper reading was carried out several times and the results were quite stable. Press consumption patterns of the 1970s and 1980s in Estonia were described by using a two-dimensional model: critical vs. non-critical attitude towards the media content and activeness vs. passivity of media consumption (Figure 1).

A similar typological analysis of media consumption was carried out on the basis of BMF Gallup Media data from spring 1997 (Lauristin and Vihalemm 1998). Although the indicators of media consumption were too different for direct comparisons, it is possible to compare empirical trends and say that polarisation between active and passive media users has become more significant among Estonians. The increase of non-selectivity is related to the changed proportions between media channels - the importance of TV watching is much higher in general media use and the importance of reading, especially newspaper reading, is remarkably lower. Non-critical media use is more widely distributed due to the growth of the role of TV. In press consumption, both activity and critical orientation have 


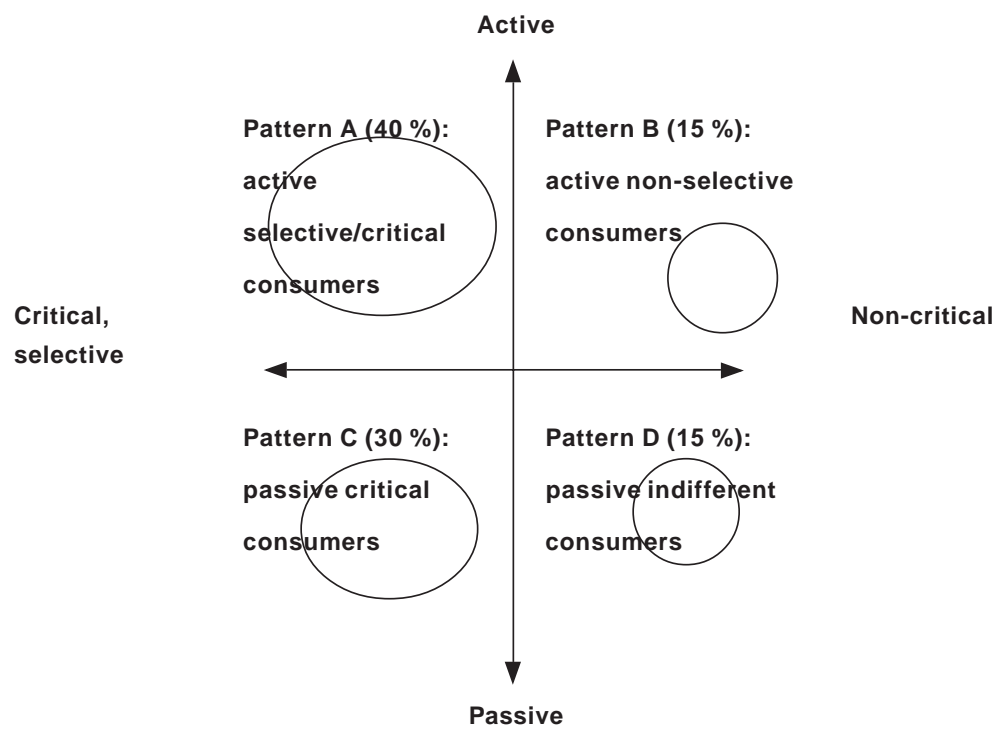

decreased. Using the typology of Figure 1 to characterise the current situation, one would conclude that the largest types of press consumption among Estonians today are not $\mathrm{A}$ and $\mathrm{C}$ but types $\mathrm{C}$ and $\mathrm{D}$.

\section{Main Theoretical Approaches ${ }^{1}$}

Western media sociology in the late 1960s departed from the functionalist approach and started to favour critical studies strongly influenced by Marxist tradition. At the same time, the methodology of empirical media research in Estonian sociology (as in Soviet sociology in general) in the 1960s and 1970s became closely linked to the theoretical paradigm of structural functionalism. Marxism, whose rhetorics was compulsory in all social science writing in the Soviet Union, could not be seriously applied as the methodological paradigm in empirical media studies because this would have inevitably led to the ideologisation of media research in the spirit of official dogmatism. A critical attitude towards the Western media and mass culture was part of everyday Communist propaganda, and this was a reason why critical approaches, popular among Western researchers in the 1960s and 1970s, did not have an emancipating influence in the conditions of the totalitarian Soviet system. The development of the critical media studies paradigm in Estonian media research started only after independence was regained.
The 1960s and 1970s, however, also saw a revolutionary development in the applications of structural functionalism for analysing the Soviet media. Media studies helped to describe a reality much different from the canonised picture disseminated and supported by the ideological state apparatus. Instead of propagated pictures of harmonious social relations and mythologies describing Soviet people as "unanimously devoted to ideals of Communism," the studies described a variety of real interests and values and examined the complicated nature of social self-regulation mechanisms and their relations with official institutions. Empirical media research had an important function supporting and encouraging journalists in their attempts to resist ideological pressure and political control, to feel themselves responsible and accountable for their people and national culture, not for the official ideological and political system. In realising this function under Soviet conditions, the functionalist approach was paradoxically more fruitful than the critical one.

In the late 1970s and in 1980s, models of uses and gratifications were implemented in various audience surveys. Because of its focus on individual choices, this approach was in overt conflict with the official concept of Soviet media as an "ideological weapon in the hands of Communist party" or a "collective propagandist and organiser of masses." Studying media consumption in the con- 
text of everyday life of people and looking at the media as a provider of practical information, as a leisure activity or as an object for critical evaluation by local opinion leaders - both activities stood far apart from the normative picture of Soviet propaganda.

It is important and interesting to mention that Estonian researchers did not implement their research paradigms simply by following examples of Western research but instead developed original communication models and methodological schemes. Unfortunately the Iron Curtain cut off these findings from international scientific debate, and media research in Estonia, as well as in other Soviet centres, remained isolated and mostly unknown to the international research community. The situation started to change in the early 1990 s and Estonian media research has since been increasingly included in international academic debate. New research projects (some described below) are primarily influenced by the theory of public sphere and critical media analysis, social constructivism, and the methodology of social representations and critical discourse analysis.

\section{Estonian Media Research in 1990s}

Changes in organisation of research. Almost a decade of independence has also been a period of development of media research into a branch of business. In 1992, the media and market research company BMF Gallup Media was established (it earlier used the name Baltic Media Facts), coowned by the Finnish Gallup and the Estonian market research company Emor. In the same year, BMF started both the National Media Survey, measuring audience structure of all printed media channels in Estonia two times per year, and the TV and Radio Diary Survey four times per year. A bit later, the Target Group Index Survey (buying habits and preferences for major kinds of products, two times per year), the Kids Media Survey and the Advertising Expenditure Survey (advertisement volumes in all media channels) were started. In 1997 the permanent monitoring of TV and radio audiences was introduced to replace the quarterly survey (Baltic Media Book 2000: 14).

As BMF Gallup Media is a highly professional organisation conducting a representative national survey every few weeks and strictly following the international rules and standards in data collection, the research groups at Estonian Radio and Estonian TV were not able to compete and thus finished their activities. Also, the Department of Journalism at Tartu University has not conducted any nationally representative surveys since the establishment of BMF Gallup Media. For academic purposes, however, it is possible to use all survey results from BMF Gallup Media (including the newest data sets). Besides data collection, BMF Gallup Media compiles and publishes a yearbook titled Baltic Media Book. Since 1998 they have also a website www.mediafacts.com, a dynamic online data collection of media facts, statistics and contacts, covering the Baltic countries and expanding into Finland and Russia. BMF Gallup Media does not have a monopoly on the media research business in Estonia; ad hoc studies are also conducted by other companies - Saar Poll (especially content analysis) and Turu-Uuringute AS.

Main research projects. Academic media studies are concentrated in the Department of Journalism at Tartu University. Five large research projects took place in the 1990 s:

- Development of the media in the Baltic countries (1991-1993) - a joint project of media scholars from Tartu, Riga, Vilnius and Oslo, supported by the Norwegian Ministry of Foreign Affairs, University of Oslo, the Foundations for Free Speech and for the Local Media in Oslo. The outcome of this project was the first extensive book about the Baltic media, Towards a Civic Society: The Baltic Media's Long Road to Freedom. It was edited by Svennik Høyer, Epp Lauk and Peeter Vihalemm, and published in Tartu in the summer of 1993. The book overviews the development of the media in the Baltic countries from the beginning of publishing in the $16^{\text {th }}$ century, concentrating on the emergence of the national press: its development during 1900-1940, the pressure of the Soviet-era and the first stages of post-Communist transition. In connection with this project, the Baltic Association for Media Research (BAMR) was established in May 1993.

Following the work that led to Towards a Civic Society, the historical and sociological approaches to the development of the Estonian media have become much closer to each other in the Department of Journalism.

- BALTICOM research program (1991-1996) - a joint project of media scholars from Tartu, Lund, Göteborg and Tampere, supported by the Swedish Royal Academy of Sciences, the Swedish Institute, the Swedish National Board of Psychological Defence, the Estonian Science 
Foundation and the Open Estonia Foundation. The main result of the project was the book $R e$ turn to the Western World: Cultural and Political Perspectives on the Estonian Post-Communist Transition (edited by Marju Lauristin and Peeter Vihalemm with Karl Erik Rosengren and Lennart Weibull, published by Tartu University Press in 1997). The book analyses civilizational, regional, social and individual contexts of Estonian transition; gives an overview of historical developments in Estonia during 1987-1997; analyses national spaces in the Baltic area; traces the development of political culture and value systems, and, last but not least, analyses changes in the Estonian media during the last decade.

- The Estonia ferry catastrophe: authorities, the media and the public (1994-1996) - a joint project of several Swedish, Finnish and Estonian media scholars on media coverage of the large ferry catastrophe on September 28, 1994, and crisis communication after the disaster, supported by the Swedish National Board of Psychological Defence. The main result of the project was presented in seven research reports, published in 1996 in Stockholm, among them two on the basis of Estonian data - The Disaster in Estonian Media (ed. by Marju Lauristin and Peeter Vihalemm) and När nyheter nadde Estland ("When the News Reached Estonia," authors Andrus Saar, Göran Stütz and Eino Tubin).

- Database and publications on media trends and research documentation in the Baltic countries (1996-1999) - a joint project of NORDICOM and BAMR, supported by the Nordic Council of Ministers. The main outcome of the project was presented in the three books: 1) NORDICOM 1996 \& BAMR 1996. Bibliography of Nordic and Baltic Mass Communication Literature media research bibliography in Estonia, Latvia and Lithuania 1995-1996; 2) Nordic Baltic Media Statistics - media development trends in Baltic countries 1990-1997; 3) Baltic Media Researchers - data about media researchers and research projects, a bibliography of media literature in the Baltic countries in 1997-1998.

- Media and social change (1997-2000) - integrates several projects dealing with different periods in Estonian history and supported by the Estonian Science Foundation and Estonian Ministry of Education. The main focus is concentrated on the last decade (development of the media system and media use in the framework of institutional and cultural changes; role of the media in integration of Russophones into Estonian society), but also analyses the Soviet period (levels and forms of ideological and political control, expressed through censorship as well as editing; conflicts between ideological control and cultural resistance) and the period of pre-war independence (from the viewpoint of changing journalistic conventions). The main outcome of the project will be the book Media and Social Change in the Baltic Countries, in which scholars from Riga, Vilnius and Oslo will also participate and which should be published in early 2001.

Another part of the project is a joint research effort with scholars from Konstanz and Tampere - Media construction of national identities in post-war Europe (nationalism and the press in Austria, Germany, Switzerland, Finland and Estonia in 1945-1995). The main outcome of this project will be a book edited by Wilhelm Kempf and Heikki Luostarinen and published in 2001.

Development of the study programs. In 1990, just prior to formal independence, the journalism curriculum like all others in Tartu University was reorganised. The requirement to follow official Soviet curriculae used by Moscow University was abolished and individual study programs were established. Tartu University introduced a system of $4+$ $2+4$, meaning 4 years of BA studies ( 160 credits, 1 credit $=40$ study hours), 2 years of MA studies (80 credits), and 4 years of doctoral studies (160 credits). Post-graduate study programs in journalism and mass communication were opened in 1992. Since then, 16 masters' theses (MA) and 2 doctoral $(\mathrm{PhD})$ dissertations have been defended (Epp Lauk in 1997 and Triin Vihalemm in 1999 - topics of dissertations are given in the bibliography).

In 1996 a BA program in public relations was started. Public relations are studied in the context of organisational and market communication, political communication and knowledge management. This new speciality has broadened the scope of academic research in the field of communications beyond the traditional media research. In the summer of 2000, master and doctoral programs in media and communication were opened. Since May 2000 the department has a new name - the Department of Journalism and Communication.

Current state of the research. Comparing the bibliographical data (Nordicom 1996 \& BAMR 1996) on media and communication research between the 
Nordic and Baltic countries in 1996 (a total of 179 publications in all three Baltic countries, compared to 334 publications in Denmark, 340 in Finland, 265 in Norway and 352 in Sweden), one can conclude that despite more than thirty years of media research, this field was still underrepresented in Baltic social sciences. The situation is improving now, as a new generation of researchers is starting their academic careers in a different environment, where from the very beginning of their research they are involved in international theoretical debate and horizon-broadening co-operation with media scholars from other European countries.

In the context of this co-operation, research interests of Estonian media scholars are currently focused on the following problems:

1) Development of the media system and media market, changes in the media use. Developments in Estonian media provide an exemplary case of extreme liberalisation and the subsequent domination of a few foreign companies in the media market. At the same time, the speed of computerisation and Internet access in Estonian society, especially among the young generation, is one of the fastest in post-Communist countries. As a result, processes of rapid fragmentation and social divergence among the audience into "information poor" and "information rich" have accelerated during the last decade.

2) Media and political communication. Developments in political culture and changes in political discourse. Problems of political domination and legitimacy. The model of relationships between the media and political forces in Estonia has switched from open partisanship at the time of the "singing revolution" to the current emphasis on autonomy and a "watchdog" attitude. Changes in public political discourse, analysed in various studies, have revealed a shift from the initial "mythological" form to "ideological" and "critical-rational" argumentation. Consider- able differences were found in the interpretation and legitimacy of reforms by comparing discourses of journalists, politicians and representatives of the general public. The comparison of political discourses in different European countries, concerning political, economic and social reforms (e.g., enlargement of the EU) and disclosing "mythologies", "ideologies" or "critical arguments," could be of great interest.

3) Changing professional culture in the media. Generational replacement of journalists. Development of journalistic conventions and discourses. This traditional area of interest for the Department of Journalism and Communication at Tartu University now has a new framework connected with the marketisation and liberation processes in Estonian society. Department scholars have followed the emergence of the journalistic profession in Estonia since the last century, comparing it with similar processes in the Nordic countries. In the last decade research has focused on the changes in the journalistic professional conventions and the convergence of genres and shifts in professional values.

4) The role of the media in the nation building processes and integration of minorities into society. Ethnic issues are at the forefront of international interest concerning developments in the Baltic countries. In this context the role of the media is being assessed in constructing national identities and in creating a common public sphere for different ethnic communities. Media monitoring of integration processes has been underway since early 1999.

Shaped by a series of dramatic changes during the last four decades, Estonian media studies are now seeking and establishing new theoretical models that will relate developments in the media and communication to the processes of societal transformation occurring in the post-Communist world.

The article is based on a paper presented at the conference Communication Science in Eastern Europe: Development and Actual Situation (1989-1999) in Leipzig on October 28-29, 1999. 


\section{Note}

1. This part of the article uses text from a lecture given by Prof. Marju Lauristin during the Third NordicBaltic Summer School on Communication Studies in Kungälv on August 14, 1999.

\section{Selected Bibliography}

Baltic Media Book 2000 (2000) Tallinn, Riga and Vilnius: BMF Gallup Media. New data also available electronically - www.mediafacts.com

Baltic Media Researchers. Bibliography of Media Literature 1997-1998 (1999) Tartu: Baltic Association for Media Research.

Harro, Halliki (1997) Change of Journalistic Conventions. Whose Speech Was Represented in Estonian Newspapers in 1920s and 1930s? In Koivisto, Juha \& Lauk, Epp (eds.) Journalism at the Crossroads: Perspectives on Research. Tartu: Tartu University Press, 93-107.

Hion, Ene; Marju Lauristin \& Peeter Vihalemm (1988) LifeStyles in Contemporary Estonia. Tallinn: Perioodika.

Høyer, Svennik; Epp Lauk \& Peeter Vihalemm (eds.) (1993) Towards a Civic Society: The Baltic Media's Long Road to Freedom. Tartu: Baltic Association for Media Research/Nota Baltica Ltd.

Kääriku I (1967) Materialõ vstrechi sociologov “Metodologicheskije problemõ issledovanija massovoi kommunikatsii" [Proceedings of the sociological conference "Methodological Problems of Mass Communication Research"]. Tartu: Tartu University.

Kääriku II (1968) Materialõ vstrechi sociologov "Tsennostnõje orientatsii lichnosti i massovaja kommunikatsija" [Proceedings of the sociological conference "Value Orientations and Mass Communication"]. Tartu: Tartu University.

Kääriku III (1969) Materialõ vstrechi sociologov "Lichnost i massovaja kommunikatsija" [Proceedings of the sociological conference "Personality and Mass Communication"]. Tartu: Tartu University.

Lauk, Epp (1996) Estonian Journalists in Search of New Professional Identity. Javnost/The Public, 3, 4, 93 106.

Lauk, Epp (1997) Historical and Sociological Perspectives on the Development of Estonian Journalism. Dissertationes de mediis et communicationibus Universitatis Tartuensis 1. Tartu: Tartu University Press.

Lauk, Epp (1999) Practice of Soviet Censorship in the Press: The Case of Estonia. Nordicom Information, 21, 3, 27-40.

Lauk, Epp (1999) Trends in the Development of the Estonian Media Market in the 1990s. Media Development, 3, 27-36.

Lauristin, Marju (1976) Analiz soderzhanija kak metod issledovanija sotsialnoi napravlennosti massovoi informatsii [Content analysis as a method of research of social orientation of mass media]. Unpublished doctoral dissertation. Tartu University, Department of the Estonian Language.
Lauristin, Marju (1982) On the Relationship between Mass Communication and Personality, Group and Mass Levels of Consciousness. In Social Role of Mass Communication. Report of the second Soviet-Finnish seminar. University of Tampere, Department of Journalism and Mass Communication, Publications, Series B, Vol. 8, 193-204.

Lauristin, Marju (1984) The Possibilities of Social Prognosis in Mass Communication Research. In City - Way of Life - Mass Communication. Report of the third Soviet-Finnish seminar. University of Tampere, Department of Journalism and Mass Communication, Publications, Series B, Vol. 13, 235-245.

Lauristin, Marju (1991) Public Participation as an Educational Process. An East European View. In Deelstra, Tjeerd \& Oleg Yanitsky (eds.) Cities of Europe: The Public's Role in Shaping the Urban Environment. Moscow: Mezhdunarodnye otnoshenia Publishers, 117-132.

Lauristin, Marju (1998) Transformations of Public Sphere and Changing Role of the Media in Post-Communist Society. In Sztompka, Piotr (ed.) Building Open Society and Perspectives of Sociology in East-Central Europe. Pre-Congress Volumes of the $14^{\text {th }}$ World Congress of Sociology. Montreal: International Sociological Association. 1998, 117-129.

Lauristin, Marju \& Boris Firsov (eds.) (1987) Massovaja kommunikatsija $i$ ohrana sredõ. [Mass communication and environmental protection]. Tallinn: Eesti Raamat.

Lauristin, Marju \& Peeter Vihalemm (1986) Raamatunõudlus ja kirjanduskultuur [Book demand and literary culture]. Keel ja Kirjandus, 7, 8, 385-393, 459-468.

Lauristin, Marju; Peeter Vihalemm; Sulev Uus \& Juhan Peegel (1987) Rajoonileht ja lugeja [Local paper and its reader]. Tallinn: Eesti Raamat.

Lauristin, Marju \& Peeter Vihalemm (eds.) (1996). Estonia: The Disaster in Estonian Media. Stockholm: Styrelsen för psykologiskt försvar.

Lauristin, Marju \& Peeter Vihalemm with Karl Erik Rosengren \& Lennart Weibull (eds.) (1997) Return to the Western World: Cultural and Political Perspectives on Estonian Post-Communist Transition. Tartu: Tartu University Press.

Lauristin, Marju \& Peeter Vihalemm (1998) Media Use and Social Changes in Estonia. In Estonian Human Development Report 1998. Tallinn: UNDP, 31-37. Also available electronically - www.undp.ee

Manaev, Oleg (1989) A Vicious Circle in Soviet MediaAudience Relations. European Journal of Communication, 4, 3, 287-306.

Misiunas, Romualdas \& Rein Taagepera (1993) The Baltic States: Years of Dependence 1940-1990. London: Hurst \& Co.

Nordic Baltic Media Statistics 1998 (1999) Göteborg: Nordicom.

NORDICOM 1996 \& BAMR 1996. Bibliography of Nordic and Baltic Mass Communications Literature (1997) Aarhus: Nordicom. 
Pärl-Lõhmus, Maarja (1997) Journalistic Editing in a Closed Society. In Koivisto, Juha \& Epp Lauk (eds.) Journalism at the Crossroads: Perspectives on Research. Tartu: Tartu University Press, 108-120.

Shlapentokh, Vladimir (1987) The Politics of Sociology in the Soviet Union. Delphic Monograph Series. Boulder: Westview Press.

Tammerk, Tarmo (1998) Legal Framework. In Schmid, Helga (ed.) Understanding the Media in the Baltic States. Düsseldorf: European Institute for the Media, 9-20.

Unt, Aune (1998) The Broadcast Media. In Schmid, Helga (ed.) Understanding the Media in the Baltic States. Düsseldorf: European Institute for the Media, 33-46.

Veskimägi, Margo \& Triin Susi (1998) Too Many Fish in the Pond?: Estonia. In Development of the Audiovisual Landscape in Central Europe since 1989. Luton: University of Luton/John Libbey Media, 111138.

Vihalemm, Peeter (1984) Mass Communication and the Development of Personality. In City - Way of Life Mass Communication. Report of the third SovietFinnish seminar. University of Tampere, Department of Journalism and Mass Communication, Publications, Series B, Vol. 13, 69-78.
Vihalemm Peeter; Epp Lauk \& Marju Lauristin (1997) Estonian Media in the Process of Change. In Lauristin, Marju \& Peeter Vihalemm with Karl Erik Rosengren \& Lennart Weibull (eds.) Return to the Western World: Cultural and Political Perspectives on Estonian Post-Communist Transition. Tartu: Tartu University Press. 1997, 227-240.

Vihalemm, Peeter \& Marju Lauristin (1997) Political Control and Ideological Canonisation. The Estonian Press during the Soviet Period. In Mühle, Eduard (Hrsg.) Vom Instrument der Partei zur "vierten Gewalt”. Marburg: Herder-Institut. 1997, 103-109.

Vihalemm, Triin (1999) Formation of Collective Identity among Russophone Population of Estonia. Dissertationes de mediis et communicationibus Universitatis Tartuensis 2. Tartu: Tartu University Press.

Vihalemm, Triin (1999) Local and Global Orientations of Media Consumption in Estonia. In Estonian Human Development Report 1999. Tallinn: UNDP, 42-49. Also available electronically - www.undp.ee

Vooglaid, Ülo (1972) Metodõ, ispolzovannõje pri issledovanii auditorii gazetõ Edasi i dejatelnosti redaktsii [Methods used for investigation of the readership of the newspaper Edasi and the activities of the editorial board]. In Vooglaid, Ülo (ed.) Trudõ po sotsiologii, Vol. II. Tartu: Tartu University. 